\title{
Challenges in Academic Reading and Overcoming Strategies in Taught Master Programmes: A Case Study of International Graduate Students in Malaysia
}

\author{
Manjet Kaur Mehar Singh ${ }^{1}$ \\ ${ }^{1}$ School of Languages, Literacies and Translation, Universiti Sains Malaysia, Malaysia \\ Correspondence: Manjet Kaur Mehar Singh, School of Languages, Literacies and Translation, Universiti Sains \\ Malaysia, Minden 11800 Penang, Malaysia. E-mail: manjeet@usm.my
}

Received: June 23, 2014 Accepted: July 22, 2014 Online Published: July 30, 2014

doi:10.5539/hes.v4n4p76 URL: http://dx.doi.org/hes.v4n4p76

\begin{abstract}
This article focuses on research into academic reading practices of international graduate students in taught Master programmes in a Malaysian university. The purpose of the study was to examine the challenges faced in the academic reading practices as well as the strategies employed to overcome the challenges in the academic reading practices. Quantitative data was collected through the Academic Literacies Questionnaire and analysed. The findings show challenges faced by international graduate students are attributed by the fact that English is the medium of instruction and English is not their first language. At the same time, the findings also highlight the strategies employed by the students to overcome the challenges in their academic reading practices. However, it was found that the students, although exposed to challenges in their academic reading practices were not very responsive toward overcoming the challenges. This article concludes with administrative policies and reading related programmes to support the unique academic reading background needs of the students and ensure their academic success.
\end{abstract}

Keywords: academic reading practice, challenge, international graduate student, Master programme, overcoming strategy

\section{Introduction}

English speaking countries have long established popularity among international students from various regions globally. However, non-English speaking countries, where English is the second language (L2), such as Malaysia, Singapore and South Africa are only currently increasingly attracting foreign students (Crewe, 2004; Reinties, Beausaert, Grohnert, Niemantsverdriet, \& Kommers, 2012). For example in Malaysia, postgraduate students from the Middle East countries contribute one of the largest blocks of students (Norhisham, Muhamad, Azizah, Osman, Abdul, \& Norpisah, 2008; Ministry of Higher Education, [MoHE], 2010).

The increasing number of international students studying in Malaysia has brought about various issues such as students coming from different linguistic, educational and cultural backgrounds. Carroll and Ryan (2005) pointed out that international students bring to an institution a diversity of competencies that have been progressively built from childhood, primary, secondary and prior tertiary learning experiences. These students have already experienced a culturally defined approach to academic literacies in learning at first-degree level in their native country's higher education system. Furthermore, the students' prior academic background has been influenced by the use of their first language (L1) for academic purposes.

Second language (L2) academic literacy research results highlight that becoming literate in different discourse traditions is a challenging, complex and lengthy process (Zhu, 2001; Casanave, 2002; Shi \& Beckett, 2002; Leki, 2003; Spack, 2004; Zamel \& Spack, 2004). It is also stressful for non-native speakers of English who may try to reconcile contradictory desires to adjust to and resist new ways of practicing academic literacy in a new education institution in a different country. Based on past research conducted in English speaking universities, researchers found non-native speakers of English face hurdles comprehending lectures, taking part in tutorial discussions, writing essays and theses, reading course books and designated articles and communicating with lecturers, supervisors and fellow students (Hellstèn, 2002; Hellstèn \& Prescott, 2004; Wong, 2004; Sawir, 2005). In the countries mentioned by Crewe (2004) and Rienties et al. (2012), especially Malaysia where English is the 
second language and is used as the medium of instruction for graduate studies (Mahmud, Amat, Rahman \& Mohd Ishak, 2010; Ministry of Higher Education, 2010) there is a wide gap in research conducted pertaining to academic literacies practices, especially academic reading practices of the international graduate students (Wahi, O'Neill, \& Chapman, 2012). This particular research study, therefore, explores the challenges faced by international graduate students in their academic reading practices in their Master programmes conducted in English language.

\subsection{Statement of the Problem}

The international graduate students attending higher education institutions in Malaysia who are highly capable and motivated have successfully met the universities' academic requirement that are the first-degree CGPA cut-off point and English language requirement. Subsequently, these students qualify to further their study at graduate level based on their English language qualifications such as the TOEFL or IELTS results. However, prior research that has explored academic literacies practices of the international graduate students in Malaysian local universities found them to be struggling in their reading and writing practices that are the thrust of academic literacies.

The non-native English speaking international graduate students' exposure to academic literacies from primary until tertiary level in their native countries has been mainly in their L1. This attribute of the students gives impact to their academic literacies practices when they come to Malaysia to further their study at graduate level. They are still unable to grasp the new and different academic expectations as well as adapt to the appropriate academic demands of their Master programmes as mentioned in studies conducted previously in Malaysian higher education institutions (Rabab'ah, 2003; Hafriza et al., 2004; Kaur \& Shakila, 2007; Hisham, 2008; Koo, 2009; Kaur \& Sidhu, 2009; Al-Khasawneh, 2010; Al-Zubaidi \& Rechards, 2010; Mahmud et al., 2010; Nambiar \& Ibrahim, 2011; Ibrahim \& Nambiar, 2011a; Ibrahim \& Nambiar, 2011b). Furthermore, to date, most investigations surrounding the international graduate students conducted locally on the academic literacies issues have heavily focused on investigating their writing practices. As Braine (2002) puts it, "a fundamental shortcoming of most studies of socially situated academic literacy is their focus on writing tasks alone” (p. 63) and also the relationship between writing practices and learning and the production of written assignments (Wahiza Wahi et al., 2012). Braine (2002) further indicates less research focuses on other academic practices such as reading and speaking.

Prior to the various research conducted in Malaysian context as mentioned above, Green (1987), Stewart and Spille (1988) and Conrad, Duren, and Haworth (1998) have provided argument that there is extremely limited literature on how students experience their master programmes, much less the effects of their experience on students themselves and literature also does not draw on students' perspectives. Therefore, the findings of this study add to the existing literature in reading at graduate level and Malaysian international education.

\subsection{Relevant Scholarship}

The idea of reading as being concerned primarily with meaning is itself socially constructed. Reading is a social practice that is often embedded in larger social and institutional contexts. Learning to read and write in these contexts is, in part, to learn the conventions, norms and standards for compliance if one is to read a discipline specific text. Furthermore, reading is also related with what is meant by understanding. Understanding consists partly of the inter-textual links the reader makes (Barnett, 1989). According to Olson and Torrance (2009), different readers in different historical periods or in different cultural contexts might create and engage with written documents in dramatically distinctive ways. Different types of reading involve special conventions for use and make different demands on readers. In addition, comprehension is active if the reader is able to read although peculiar words are missing or not known.

In the context of literacy, reading is a set of skills that can be broken into parts, taught and tested. However, reading is not simply a matter of applying skills to reading. Reading is central to the subject area. The process of reading involves not only taking the meaning from the text but also interacting with the text. Alderson (2000) argues that it involves bringing knowledge to a text. There can be no effective analysis, comprehension and application without reading as a basis. Good reading skills are vital for students to understand the concepts and in turn transmit their competency in written and oral communication tasks.

Moreover, in academic reading, one is expected to distance oneself from the text in an objective way in order to evaluate its validity, biasness and assumptions. One of the major characteristic of the voice of an academic proficient reader and proficient writer is authority. Blanton (1994, p. 230) suggests that the student is viewed as powerless without such an authority. A reader should also become personal to evaluate and speculate on the text in relation to one's own reactions, concerns and professional interest. 
In the context of the present study, there arises necessity for graduates to be able to critically evaluate what is read and use critical thinking to explain their understanding of the reading. Atkinson and Longman (2003) stresses that practice in critical thinking helps students to find, sort, evaluate and choose wisely through the vicarious experience of reading. However, lack of competence in reading can negatively affect the written and spoken output of the student and influence its role as an essential foundation skill in discussing and writing at graduate level.

\subsection{Related Studies on Academic Reading Practices among International Graduate Students}

Reading problems and the expected outcomes have been cited as one of the most neglected problems facing the international graduate students (Smith, 1998). Phakiti and Li (2011) highlighted that their postgraduate respondents faced difficulty in extracting and synthesizing information from various sources and recognizing and acquiring academic vocabulary for use. Studies by Burke (1996) with postgraduate Australian students whose first language is not English, Borland and Pearce (1999) and Cheng, Myles, and Curtis (2004) with international students whose mother tongue is not English highlighted some of the problems with reading. The findings by Burke (1996) indicated that new discipline-specific terminology was a major cause of difficulty. Burke (1996) and Cheng et al. (2004) also found international students consume more time to read as it is done slowly, depend heavily on dictionaries and re-read a text several times.

These challenges mentioned by the researchers above affect the students' ability to read and engage in critical discussions of academic texts. Reid, Kirkpatrick, and Mulligan's (1998) research finding is also consistent with Burke's that overseas students take two to three times longer to read an academic text than an English-speaking background student. In addition, unfamiliarity with English speaking study environment affected students with linguistic and cultural challenges such as ascertaining the degree of how much critical analysis is required in a discipline, interpreting unfamiliar texts and lastly, expressing their criticality in the discourse appropriate for that discipline.

In a study conducted by Borland and Pearce (1999), it was found that reading critically is a challenge for most students and most commonly, they ascribe their difficulty to lack of time. Second language learners tend not to read as much as an L1 learner as their reading is slower. Second language learners spend a lot of time trying to understand the material with consequently less time and confidence available to reflect critically on it. Durkin (2004) also mentioned some issues that can arise in reading and writing critically such as misunderstanding of concept of scholarly critical evaluation, difficulties with the concept of critical reading, the cultural inappropriateness of challenging scholarship for some students, difficulties in analysing essay questions and differences in the way different cultures structure literary texts.

In addition, Koda's (1995) study show that students from four different cultural backgrounds where written texts used different orthographic structures (Arabic, English, Japanese and Spanish) used different information processing procedures for reading English text. It was highlighted that although native speakers of English experienced difficulty in reading, non-native speakers of English were seen to be at a particular disadvantage in comprehending what is being said and the cultural implications underpinning much of the material which native speakers can comprehend with little difficulty. Thus, Koda cautions that while for L1 students is likely that good readers tend to be good writers and good writers usually display more regular and more sophisticated reading patterns, the transfer to L2 should not be assumed too readily.

Wilson (2003) also concedes to the serious difficulties faced by overseas students in academic reading. Her research concludes that overseas students who have little experience of academic texts struggle with reading large volume and time-consuming nature of reading. Another study by Pretorius (2005) showed that students with poor reading skills seldom achieve academic success. Niven (2005) also postulates that academic reading is pre-eminent: it precedes academic writing and determines its depth and quality. Her study revealed that students rarely applied reading strategies that would ensure the sort of comprehension that is aligned with the required level of learning. When lecturers' reading frames are explored, there is a marked and significant gap between lecturer expectations and student realities.

Furthermore, Loewy and Vogt (2000) add that international students may be unused to the discourse patterns used in written text. Vocabulary knowledge may not be broad enough for complete comprehension and requires dictionary use and re-reading. In one of the latest studies by Johnson (2008), international students found it difficult to understand assignment requirements, often because they thought the topic was 'too general' or they did not understand the instructional words such as 'evaluate' or 'discuss'. 
Other studies that have researched on the challenges faced by international students also have some implications for the present study. Several studies have revealed that students whose first language is not English need to spend twice and even three times longer than native speakers to finish reading and it takes time for them to form the habit of critical reading for academic purposes (Goodman, 1976; Reid et al., 1998; Durkin, 2004). Therefore, significant findings in reading challenges faced by the students indicate that academic reading practices challenges is an area which is worth investigating among international graduate students in Malaysian higher education context.

\subsection{Objectives of the Study}

This study looks into a less researched area that is the challenges experienced by the international graduate students in the academic reading practices and the strategies employed to overcome the challenges in academic reading practices. The objectives of the study are to identify:

- the challenges faced by the international graduate students in their academic reading practices in the taught Master programmes,

- the strategies employed by the international graduate students to overcome the challenges faced in their academic reading practices in the taught Master programmes.

\section{Method}

This article reports on part of a larger study (Manjet, 2013) which also examines the academic literacies challenges faced by international graduate students. The site of the research is one of the higher education institutions in Malaysia that offers various first-degree and graduate courses with an enrolment of more than 20,000 local and international students. The institution has graduate students from more than 50 countries all over the world due to the proliferation of its taught Master programmes and to the remarkable record of accomplishment in sustaining world class education quality with global recognition (Institute of Postgraduate Studies Website, 2012). Table 1 provides the conceptual framework of the study. The dependent variable is academic reading practices that are influenced by the challenges faced by the international graduate students and strategies employed to overcome the challenges in their coursework or mixed mode Master programmes in the Arts, Hybrid and Sciences schools at the research site university.

\subsection{Participant Characteristics}

The criteria for inclusion of the students in the study are as follow: (a) respondents have to be full-time international master students in the taught Master programmes; (b) they have to be in their second semester or later; and (c) they have to be registered students in the schools of Arts, Hybrid or Science at the research site university.

\subsection{Sampling Procedures}

This quantitative study utilised purposive sampling with the aim of selecting all accessible respondents who could provide accurate and reliable information regarding the research problem (Teddlie and Yu, 2007; Rubin and Babbie, 2009; Teddlie and Tashakkori, 2009).

\subsubsection{Sample Size}

Data obtained from the Institute of Postgraduate Study (IPS) of the research site university indicated there were 203 international graduate students registered in the 13 coursework and 11 mixed mode Master programmes offered in the 10 schools comprising three Arts, two Hybrid and five Sciences. One hundred and thirty one respondents in the age range of 20 to 47 years from the taught Master programmes completed the questionnaire.

\subsubsection{Measures}

The Academic Literacies Questionnaire (ALQ) items used to collect data for this study was selected from Chang (2006) and Evans and Green (2007). Ten items focused on academic reading challenges and five items focused on overcoming strategies. The ALQ was used to learn about the challenges faced by the students in their academic reading practices and the strategies taken by them to overcome the challenges. Evans \& Green's questionnaire is considered suitable to be adapted for this study as it has been pilot tested with 175 subjects and modified based on the responses obtained. The final version was administered to almost 5000 students with significant findings (Evans \& Green, 2007). Chang's questionnaire that was used for a thesis research has also produced reliable and valid data (Chang, 2006). Demographic and background information of respondents were also collected. The respondents were asked to assess the difficulty level of the challenges in academic reading practices on a scale from 1 (very difficult) to 4 (very easy). The respondents were also requested to indicate whether they employed the strategies to overcome the challenges. The data collected were subjected to 
descriptive statistics, non parametric statistics (Mann-Whitney U Test and Kruskal Wallis Test) and frequency using the SPSS software. Figure 1 indicates the conceptual framework of the study.

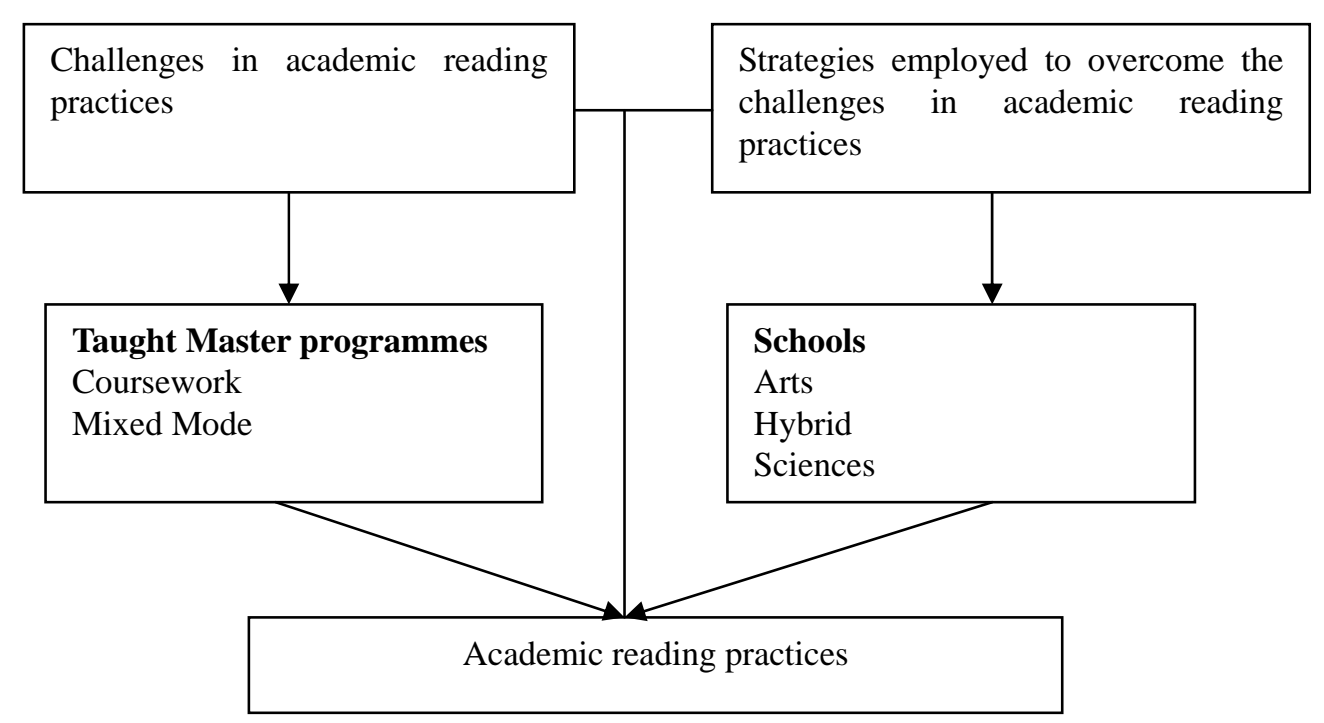

Figure 1. Conceptual Framework of the Study

\section{Results}

\subsection{Profile of the Respondents}

The frequency distribution of each demographic factor was recorded and converted into percentage (\%). Majority of the students are from the Middle East countries (64.4\%). Iran has the highest number of respondents (26.5\%), followed by Iraq (14.4\%), Palestine (6.8\%), Libya (6.1\%), Yemen (3.8\%), Jordan (3.0\%), Saudi Arabia (2.3\%) and Egypt (0.8\%). The respondents from other Asian and African countries account for $35.6 \%$. Slightly less than half of the respondents $(49.6 \%)$ were from the five schools in the Sciences. This was followed by $29.0 \%$ of the respondents from two Hybrid schools and $21.4 \%$ of the respondents from three Arts schools. Table 1 describes the distribution of students according to their schools.

Table 1. Distribution of students according to the schools

\begin{tabular}{lll}
\hline Category of Schools & No. of Respondents & $\%$ \\
\hline Sciences (5 schools) & 65 & $49.6 \%$ \\
Hybrid(2 schools) & 38 & $29.0 \%$ \\
Arts (3 schools) & 28 & $21.4 \%$ \\
Total & 131 & $100 \%$ \\
\hline
\end{tabular}

\subsection{Results of the Reliability Test}

A pilot study was administered to a small sample $(\mathrm{n}=21)$ similar to the potential respondents. It helped to determine the consistency between multiple measurements of a variable (Hair et al., 2006). The Cronbach Alpha reliability coefficient values indicate relatively high internal consistency with higher values than the minimum accepted value of 0.70 (George \& Mallery, 2003; Pallant, 2010). The result of the pilot study indicated high internal consistency reliability with the alpha coefficient of .822. The statistical analysis indicated that the ALQ has high internal consistency reliability. Table 2 describes the items in the academic reading practices section of the ALQ. 
Table 2. Academic Reading Practices Items in the Academic Literacies Questionnaire (ALQ)

\begin{tabular}{|c|c|c|}
\hline Section & Description & Likert Scale \\
\hline \multirow[t]{2}{*}{ Academic Reading Practices } & $\begin{array}{l}\text { 1. } 10 \text { items selected from } \\
\text { Evans and Green (2007) }\end{array}$ & $\begin{array}{l}1=\text { Very difficult } \\
2=\text { Difficult } \\
3=\text { Easy } \\
4=\text { Very easy }\end{array}$ \\
\hline & $\begin{array}{l}\text { 2. Two items on strategies } \\
\text { taken to overcome the } \\
\text { challenges in academic } \\
\text { reading practices selected } \\
\text { from Chang (2006) }\end{array}$ & $\begin{array}{l}\text { Choose as many strategies } \\
\text { employed to overcome } \\
\text { academic reading practices } \\
\text { challenges }\end{array}$ \\
\hline
\end{tabular}

\subsection{Challenges in Academic Reading Practices}

Sixty seven respondents from the coursework and 64 respondents from the mixed mode Master programmes used a Likert scale ranging from one ('very difficult') to four ('very easy') to assess the degree of difficulty they experienced in the 10 items on academic reading practices in the questionnaire. Scale one (very difficult) and scales two (difficult) are combined for reporting purpose. Scale three (easy) and scale four (very easy) are also combined for reporting purpose. The study has set a mean of 2.5 or above to indicate some degree of ease in the academic reading practices challenge in the ALQ based on the previous research by Evans and Green (2007). In cases where the data shows significant result for an individual scale, it is reported individually.

Table 3 summarises the respondents' evaluation on the difficulty level of the academic reading practices.

Table 3. Challenges in Academic Reading Practices

\begin{tabular}{llllll}
\hline Challenges in Academic Reading Practices & $\begin{array}{l}\mathbf{1} \\
\mathbf{( \% )}\end{array}$ & $\begin{array}{l}\mathbf{2} \\
\mathbf{( \% )}\end{array}$ & $\begin{array}{l}\mathbf{3} \\
\mathbf{( \% )}\end{array}$ & $\begin{array}{l}\mathbf{4} \\
\mathbf{( \% )}\end{array}$ & Mean \\
\hline Reading quickly to find information & 8.3 & 44.7 & 40.2 & 4.5 & 2.42 \\
Working out meaning of difficult words & 2.3 & 49.2 & 38.6 & 7.6 & 2.53 \\
Reading quickly to get overall meaning & 8.3 & 42.4 & 40.9 & 6.1 & 2.46 \\
Understanding specialist vocabulary & 8.3 & 41.7 & 40.9 & 6.1 & 2.46 \\
Identifying supporting ideas/examples & 2.3 & 32.6 & 55.3 & 6.8 & 2.69 \\
Taking brief, relevant notes & 1.5 & 30.3 & 59.1 & 6.8 & 2.73 \\
Using own words in note taking & 1.5 & 28.8 & 57.6 & 9.8 & 2.78 \\
Reading carefully to understand a text & 1.5 & 27.3 & 61.4 & 7.6 & 2.77 \\
Identifying key ideas & 3.0 & 25.0 & 60.6 & 8.3 & 2.77 \\
Understanding key ideas & 2.3 & 22.0 & 65.2 & 6.1 & 2.79 \\
\hline
\end{tabular}

Note: Scale: 1 = Very Difficult, 2 = Difficult, 3 = Easy, 4 = Very Easy

Reading quickly to find information, reading quickly to get overall meaning and understanding specialist vocabulary are ranked as the three top challenges in academic reading practices (mean ranging from 2.42 to 2.46). The respondents indicated the other seven items of challenges in academic reading practices range from difficult to easy. The findings indicate that respondents generally find reading to be a challenging academic literacies practice.

The data in Table 3 indicates that reading quickly to find information is the most difficult (8.3\%) and difficult (44.7\%) academic reading practice. The respondents reported working out meaning of difficult words and reading quickly to get overall meaning as very difficult (51.5\%) and difficult (50.7\%). Half of the respondents (50\%) reported understanding specialist vocabulary as a combination of very difficult (8.3\%) and difficult (41.7\%). Identifying supporting ideas/examples, taking brief, relevant notes, using own words in note taking, reading carefully to understand a text, identifying key ideas, understanding key ideas are reported as easy and very easy by more than $50 \%$ of the respondents. Understanding key ideas is reported by $71.3 \%$ of the respondents to be easy and very easy.

Mann-Whitney U test, a non-parametric test for two independent samples carried out to compare the difficulty level of the academic reading practices between the coursework and mixed mode respondents revealed a 
significant difference in the difficulty level of identifying key ideas between the coursework and mixed mode respondents $(\mathrm{Z}=2.087, \mathrm{p}=.037)$. The finding indicates that identifying key ideas is more difficult for the coursework respondents (mean $=69.63$ ) compared to the mixed mode respondents (mean $=58.87$ ). The test also revealed a significant difference in the difficulty of understanding specialist vocabulary between the coursework and mixed mode respondents $(\mathrm{Z}=2.309, \mathrm{p}=.021)$. The finding indicates that understanding specialist vocabulary is more difficult for the coursework respondents (mean $=70.75$ ) compared to the mixed mode respondents (mean $=57.63)$.

Kruskal-Wallis Test, a non-parametric test of four scales carried out to compare the difficulty level of the academic reading practices among the respondents in the Arts, Hybrid and Sciences schools revealed a significant difference in the difficulty level of understanding key ideas among the respondents in the Arts, Hybrid and Sciences (Chi-Square $(\mathrm{H})(2)=7.725, \mathrm{p}=.021)$. The finding indicates that understanding key ideas is the most challenging academic reading practice for the respondents in the Arts (mean $=76.05$ ) compared to those in the Hybrid (mean = 64.36). Understanding key ideas is the easiest academic reading practice for the respondents in the Sciences (mean $=57.10$ ).

\subsection{Overcoming the Challenges in Academic Reading Practices}

Table 4 shows the frequency count of the five overcoming strategies employed by the respondents to overcome the challenges in their academic reading practices.

Table 4. Overcoming the Challenges in Academic Reading Practices

\begin{tabular}{lcc}
\hline Overcoming the Challenges in Academic Reading Practices & $\begin{array}{l}\text { YES } \\
\mathbf{( \% )}\end{array}$ & $\begin{array}{l}\text { NO } \\
\text { (\%) }\end{array}$ \\
\hline Read the assigned material more times & $72.5 \%$ & $27.5 \%$ \\
Read extensively in your discipline area & $34.4 \%$ & $65.6 \%$ \\
Refer to your first language text/material for reference & $28.2 \%$ & $71.8 \%$ \\
Use a dictionary & $71.8 \%$ & $28.2 \%$ \\
Read articles with a focus on mastering English speakers' language use & $23.7 \%$ & $76.3 \%$ \\
\hline
\end{tabular}

Based on frequency count, the findings indicate that the most vital strategies employed by the respondents are "Read the assigned material more times" (72.5\%) and "Use a dictionary" (71.8\%). The least popular strategies among the respondents are "Read articles with a focus on mastering English speakers' language use" (76.3\%) and "Refer to your first language text/material for reference" (71.8\%).

Mann-Whitney U test, a non-parametric test for two independent samples carried out to compare the overcoming strategies employed by the coursework and mixed mode respondents to overcome the challenges in academic reading practices revealed significant difference in "Refer to your first language text/material for reference" $(\mathrm{Z}=$ 2.014, $\mathrm{p}=.044$ ). The finding indicates that referring to first language text/material for reference is employed more by the mixed mode respondents (mean $=71.41$ ) compared to the coursework respondents (mean $=60.99$ ).

The findings from Likert scale items and open-ended response revealed that the challenges in academic reading practices were lengthy reading duration and understanding of what is read. More specifically, the respondents experienced challenges in reading quickly to find information, reading quickly to get overall meaning and understanding of specialist vocabulary. The less challenging academic reading practices were the understanding of key ideas and using own words in note taking.

\section{Discussion}

Doing academic reading in a particular situated context at times causes the challenges with academic reading rather that the international graduate students themselves. Academic reading practices and knowledge the students bring from their prior academic learning background and culture influence the current notions of academic reading practices and socialisation in the Master's community of practice at the research site university. Cultural variations in discourse patterns and previous learning patterns affect how academic reading is done in the Master's context. These influences did not help them to grasp and adapt quickly to the new and different academic expectations in the Master programmes. Previous research has indicated that to become accustomed to an unfamiliar culture and to a new education system, as well as navigating these differences in a foreign or L2 (Andrade, 2008; Campbell \& Li, 2008) is a lengthy process.

It was also found that being qualified as competent users of English language based on the language requirement 
(TOEFL, IELTS, or its equivalent) set by the university does not ensure that the international graduate students do not struggle with the academic reading practices at Master's level. The findings of this study strongly advocate that being non-native speakers of English and attaining required English language qualification, the students still faced academic literacies challenges in reading. The students need to be assisted with more trainings and preparation to face the academic literacies challenges. This is necessary as the respondents' English language qualifications are not the true indicator of their English language proficiency. Furthermore, their first-degree academic literacies training did not provide strong foundation to proceed to the graduate level. Hellsten (2002), Hellsten and Prescott (2004), Wong (2004) and Sawir (2005) also confirmed similar results that students' language barrier is one of the most known and widely recognised influence on the academic literacies challenges.

Many of the respondents confirmed that low proficiency in English language prevented them from taking part in academic literacies practices such as reading fluently and comprehending the material read. According to Ringbom (1987: 113-114) and Odlin (1989; 77-80), a justification for this challenge is the language distance between their L1 and L2 or third language has effect on the amount of transfer that can take place between languages. Ringbom explained that for example, the Arabic speakers take a longer time to acquire English vocabulary because transfer from third languages seems to depend very much on relative language distance. This situation makes it difficult for them to learn English language. A research finding by Andrade (2006) is also consistent with this study's finding that international students compensate for their low level of English language proficiency and socio-cultural knowledge through effort, study habits and self-help strategies.

The students encountered difficulties in many academic tasks negotiated in their graduate study. The source of their struggle in their reading was the lack of strong background in their discipline content knowledge. Repeated re-reading to understand a text was a common trend among the respondents. They highlighted that they put in more effort and time into their reading compared to the local students. At times, they translated the text from English into their native language to read and understand. Then, the text was translated into English again to read and understand. Borland and Pearce (1999) found that reading critically is a challenge mainly due the lack of time. Students whose L2 is English can take a third to two-times as long to read as L1 students, often reading a text over and over to gain understanding. Therefore, L2 learners tend not to read as much as L1 learners as their reading is slower and they spend a lot of time trying to understand the material with consequently less time and confidence available to reflect critically on it.

The respondents had to depend extensively on dictionaries and re-read a text several times as they were overpowered by the new discipline-specific terminologies. This challenge is cognitively very demanding. Burke (1996) also identified similar predicaments in his study. Burke stated a new challenge for many international graduate students in their ability to read and engage in critical discussions of academic texts with the use of new discipline-specific terminology. Bell (2000) and Nambiar and Ibrahim (2011) indicated that these challenges in academic reading practices present a heavy burden on the international students who have little experience of studying in an English speaking environment. In relation to students' different culture and background knowledge influencing their learning, there is a dire need for schemata for the international graduate students to make the necessary connection to the academic context and expectations.

Nambiar and Ibrahim (2011) similarly echoed that a translator is a useful tool to deal with unfamiliar lexicon in literacies practices. The respondents also depended heavily on lecture notes and the lecture notes became their only source of reading. This was found to be consistent with other studies carried out by Van Meter, Yokoi and Pressley (1994) and Harklau (2001) that students depended on the lecture notes and did not take the initiative to do further reading. Beaufort (2005) also indicated that serious engagement especially with the genre knowledge is difficult without guidance from within the community that uses the genre especially the lecturers.

In addition, it is consistent with research on student engagement in higher education by Christie, Munro and Fisher (2004). Christie et al. indicated most students tend not to actively seek assistance to overcome the academic literacies challenges. Trotter and Roberts (2006) added that the international students do not seek assistance because universities provide poorly articulated orientation programmes, students' own inability to self-assess their learning needs, disappointment with performance in courses and lack of awareness of what help is available or how to access it. When the respondents are confronted by academic challenges such as reading a research paper, there is high possibility that absence or lack of the 'correct' understanding of the academic culture might lead the respondents to apply their earlier held assumptions, values, beliefs and approaches that had given them stability, consistency and meaning (Schein, 2004).

Therefore, this research presents four vital recommendations that would assist the international graduate students 
in handling the challenges in their academic reading practices. Firstly, the lack of strict enforcement on the English language entry requirement by either the individual schools or the Institute of Postgraduate Studies at the research site university needs to be improved and adhered to. Concurrently, the university should also not only depend on the standardised English language requirement across the board for all the taught Master programmes. Alco's (2008) study has found IELTS and TOEFL not to be consistently reliable indicators of language ability in the academic setting. Therefore, the university should also look into the possibility of designing and implementing a more effective in-house standardised English language placement test to evaluate students' English language proficiency. Students' results in this test will be a good indicator of their reading preparedness to enroll into the programmes of their choice at the research site university. Furthermore, the in-house standardised English language placement test is necessary to categorise students based on their language qualification into linguistically demanding and non-linguistically demanding Master programmes as these programmes require different levels of English language proficiency.

Secondly, in order to ensure the development of effective learning that will enable the international graduate students to become skilled readers within the graduate education environment, the research site university should enhance teaching and learning through trans-disciplinary collaboration between content and language specialists' lecturers. Trans-disciplinary collaboration is a new field that is not yet given the deserved attention in Malaysian universities. Lecturers from both areas should also be encouraged to cross the boundaries of their discipline, collaborate and become familiar with a wide range of disciplines. Language specialists should be trained to become familiar with the effective reading techniques to prepare the students to handle the discipline specific concepts and the language of the particular discipline. At the same time, the content lecturers should be trained on the linguistic aspects and the academic reading practices demands of their discipline. The expertise of both area lecturers can be employed to create integrative language and content instruction courses that focus on specific discourses within the discipline to bring about an optimum exposure of the academic reading expectations to the students.

Academic Book Club programmes should also be implemented at the universities to cultivate the habit of reading and proceeding with Book Club discussions. Activities of this nature will encourage the students to increase their reading frequency and concurrently improve their academic socialisation with other academic members of their graduate community through discussions.

Lastly, this study also recommends that the lecturers' role as educators should be enhanced to accommodate the teaching of international students. The enhancement of the lecturers' role as educators should focus on educating lecturers on the intercultural diversity of the international graduate students in the context of how the students approach reading activities or tasks. Lastly, the implications of the results for improvement of the international graduate students' academic reading experience at the research site university are significant. The research site university's academic fraternity needs to accept the students with clear teaching and learning plan that addresses the multifaceted nature of the linguistic and cultural background of the coursework and mixed mode Master programmes' international students.

\section{Conclusion}

In conclusion, this study has revealed how the international graduate students in the taught Master programmes that bring with them academic reading experiences that differ from the present institutionally accepted codes and conventions faced the challenges in their academic reading practices and employed strategies to overcome the challenges. The findings present only a small part of a much larger picture of the academic endeavour especially the academic reading experience of the students within a broader context of their past and present cultural, linguistic and educational experiences. It is hoped that this study has shed some light on the academic challenges such as in reading that international graduate students experience. As such, an understanding of learning process of international graduate students is pivotal to ensure their academic success. The study also reaffirms the idea that "an understanding of literacy requires detailed, in-depth accounts of actual practice in different cultural settings" (Street, 1993) and the situatedness of academic reading are multiple, changing and different from one academic context to another (Lea \& Street, 2000). Finally, the recommendations provided in this research should be seriously considered by all the involved parties to ensure a positive learning experience for the international students. 


\section{References}

Alco, B. (2008). Negotiating Academic Discourse in a Second Language: A Case Study and Analysis (Unpublished doctoral dissertation). The Pennsylvania State University, United States of America.

Alderson, J. C. (2000). Asessing Reading. http://dx.doi.org/10.1017/CBO9780511732935

Al-Khasawneh, F. M. S. (2010). Writing for academic purpose: problems faced by Arab postgraduate students of the College of Business, UUM. ESP World, 2(28), Volume 9. Retrieved from http://www/esp-world.info

Al-Zubaidi K. O., \& Rechards, C. (2010). Arab Postgraduate Students in Malaysia: Identifying and overcoming the cultural and language barriers. Arab World English Journal (AWEJ), 1(1), 107-129.

Andrade, M. S. (2006). International students in English-speaking universities: Adjustment factors. Journal of Research in International Education, 5(2), 131-154. http://dx.doi.org/10.1177/1475240906065589

Andrade, M. S. (2008). International graduate students: Adjusting to study in the United States. In K. A. Tokuno (Ed.), Graduate Students in Transition: Assisting Students through First Year. No.50 (pp.71-90). University of South California, LA.

Atkinson, R. H., \& Longman, D. G. (2003). Reading Enhancement and Development. Boston: MA. Thomson and Heinle.

Barnett, M. A. (1989). More than Meets the Eye: Foreign Language Reading, Theory and Practice. Englewood Cliffs, NJ: Prentice Hall.

Beaufort, A. (2005, June). Do writing skills transcend cultures? A look at writing expertise. Paper presented at the meeting of the European Association for the Teaching of Academic Writing. Greece: Athens.

Bell, J. (2000). Framing and Text Interpretation Across Languages and Cultures: A Case Study. Language Awareness, 9(1). http://dx.doi.org/10.1080/09658410008667133

Blanton, L. L. (1994). Discourse, artefacts and the Ozarks: understanding academic literacy. Journal of Second Language Writing 3 (1): 1-16. Reprinted (as Chapter 17: 219-235). In V. Zamel \& R. Spack (Eds.), Negotiating academic literacies: teaching and learning across languages and culture (pp. 219-236). New Jersey: Lawrence Erlbaum Associates.

Borland, H., \& Pearce, A. (1999). Valuing Diversity: Experiences and achievements of NESB students at Victoria University. Melbourne: Victoria University of Technology: Centre for Educational Development and Support.

Braine, G. (2002). Academic literacy and nonnative speaker graduate student. Journal of English for academic purposes, 1(1), 59-68. http://dx.doi.org/10.1016/S1475-1585(02)00006-1

Burke, E. (1996). Academic and non-academic differences: Perceptions of graduate non-English speaking background students. TESL-EJ 2(1). Retrieved from http://www.tesl-ej.org/wordpress/issues/volume2/ej05/ej05a1/

Campbell, J., \& Li, M. (2008). Asian students' voices: an empirical study of Asian students'learning experiences at a New Zealand university. Journal of Studies in International Education, 12(4), 375-396. http://dx.doi.org/10.1177/1028315307299422

Carroll, J., \& Ryan, J. (2005). Teaching international students: Improving learning for all. Abingdon: Routledge.

Casanave, C. P. (2002). Writing games: Multicultural case studies of academic literacy practices in higher education. Mahwah, NJ: Erlbaum.

Chang, E. C. (2006). An Investigation into the thesis/dissertation writing experiences of Mandarin speaking Masters Students in New Zealand (Unpublished master thesis). Auckland University of Technology, New Zealand.

Cheng, L., Myles, J., \& Curtis, A. (2004). Targeting language support for non-native English-speaking graduate students at a Canadian university. TESL Canada Journal, 21(2), 50-71.

Christie, H., Munro, M., \& Fisher, T. (2004). Leaving university early: Exploring the differences between continuing and non-continuing students. Studies in Higher Education, 29(5), 617-636. http://dx.doi.org/10.1080/0307507042000261580

Conrad, C. F., Duren, K. M., \& Hawoth, J. G. (1998). Students' Perspectives on Their Master’s Degree Experiences: Disturbing the Conventional Wisdom. New Direction in Higher Education. No. 101. 
Crewe, I. (2004, July). UK Universities, Europe, and the globalization of higher education. Speech addressed to the Centre for Reform on July 13, 2004, Westminister, United Kingdom.

Durkin, K. (2004). Challenges Chinese students face in adapting to academic expectations and teaching/learning styles of UK masters courses: how cross cultural understanding and adequate support might aid them to adapt. Discussion Paper. London: British Council.

Evans, S., \& Green, C. (2007). Why EAP is necessary: A survey of Hong Kong tertiary students. Journal of English for Academic Purposes, 6(1). 3-17. http://dx.doi.org/10.1016/j.jeap.2006.11.005

Goodman, K. S. (1976). Reading: a psycholinguistic guessing game. In: Singer, H., Rudell, R. B. (Eds.), Theoretical Models and Processes of Reading (497-508). Newark, DE: International Reading Association,

George, D., \& Mallery, P. (2003). SPSS for Windows step by step: A simple guide and reference, 11.0 update (4th ed.). Boston: Allyn \& Bacon.

Green, J. L. (Ed.) (1987). The Master's Degree: Jack of All Trades. Denver: State Higher Education Executive Officers.

Burhanudeen, H., Stapa, S. H., Awal, N. M., Vengadasamy, R., Abdul, N. Z., Hamid, \& Mis, M. A. (2004). Empowering postgraduate students with academic writing skills:A case study of international students at Universiti Kebangsaan Malaysia. Retrieved from http://www.herdsa.org.au/conference2004/Contribution/NRPapers/A050-jt.pdf

Hair, J. F., Anderson, R. E., Tatham, R. L., \& Black, W. C. (2006). Multivariate data analysis (6th ed.). London: Prentice Hall International.

Harklau, L. (2001). From high school to college: Student perspectives on literacy practices. Journal of Literacy Research, 33, 33-70.

Hellstèn, M. (2002). Students in transition: needs and experience of international students in Australia. Paper presented at the 16th Australian International Education Conference, Hobart, Tasmania.

Hellstèn, M., \& Prescott, A. (2004). Learning at university: The international students experience. International Education Journal, 5(3), 344-351.

Hisham, D. (2008). Needs analysis of Arab graduate students in the area of EAP: A case study of the ICT program at UUM (Unpublished manuscript). Universiti Utara Malaysia Press, Sintok.

Ibrahim, N., \& Nambiar, R. (2011a). What is the problem with the statement of problem: the case of international students and the introductory sections of a project problem. Procedia Social and Behavioral Sciences, 15, 1713-1717. http://dx.doi.org/10.1016/j.sbspro.2011.03.356

Ibrahim, N., \& Nambiar, R. (2011b). Writing in foreign lands: The case of postgraduate international students and the introductory sections of a project paper. Procedia-Social and Behavioral Sciences, 18(2011), 626-632.

Johnson, M. E. (2008). An investigation into pedagogical challenges facing international tertiary-level students in New Zealand. Higher Education Research and Development, 27(3), 231-243. http://dx.doi.org/10.1080/07294360802183796

Kaur, S., \& Manan, S. A. (2007). The Learning Experience of Postgraduate Students: Emergent Themes. Bulletin of National Higher Education Research Institute (IPPTN), 9, 26-28.

Kaur, S., \& Sidhu, G. K. (2009). A Qualitative Study of Postgraduate Students' Learning Experiences in Malaysia. International Education Studies, 2(3), 47-56. http://dx.doi.org/10.5539/ies.v2n3p47

Koda, K. (1995). Cognitive processes in second language reading (orthography, cognition, bilingualism). In I. Taylor \& D. R. Olson (Eds.), Scripts and Literacy. Dordrecht: Kluwer Academic Publishers.

Koo, Y.L. (2009). Mobilising Learners through English as Lingua France (EFL): Providing Access to Culturally Diverse International Learners in Higher Education. Research Journal of International Studies, (9), 74-87.

Lea, M. R., \& Street, B.V. (2000). Student writing and staff feedback in higher education: An academic literacies approach. In M. R. Lea \& B. Stierer (Eds.), Student writing in higher education (pp.32-46). London: SRHE: Open University Press.

Leki, I. (2003). Living through College Literacy: Nursing in a Second Language. Written Communication, 20(1), 81-98. http://dx.doi.org/10.1177/0741088303253571 
Loewy, D., \& Vogt, G. (2000). Sharing the responsibility of communication. Journal for International Business, 11(1), 83-92.

Mahmud, Z., Amat, S., Rahman, S., \& Mohd Ishak, N. (2010). Challenges for International Students in Malaysia: Culture, Climate and Care. Procedia Social and Behavioral Sciences, 7(C), 289-293. Retrieved from www.sciencedirect.com.

Manjet, K. (2013). Investigating the Academic Literacies Challenges of International Graduate Students in Master Programmes in an Institution of Higher Education in Malaysia. (Unpublished doctoral dissertation). Universiti Sains Malaysia, Malaysia.

Ministry of Higher Education (MOHE). (2010). Perangkaan Pengajian Tinggi Malaysia. Ministry of Higher Education, Kuala Lumpur.

Nambiar, R., \& Ibrahim, N. (2011). Mainland China undergraduate learners' experiences in the Malaysian tertiary context. Procedia Social Behavioral Sciences, 15, 3227-3231. Retrieved from www.sciencedirect.com

Niven, P. M. (2005). Exploring first year students' and their lecturers' constructions of what it means to read in a humanities discipline: A conflict of frames? South African Journal of Higher Education, 19(4), 777-789.

Mohamad, N., Jantan, M., Omar, A., Mohamad, O., Abdullah, A. G. G., \& Isa. N. M. (2008). Internationalisaton and International Linkages: The State of Malaysian Higher Education Institutions. In Z. M. Don, Y. A. Bakar, A. H. Mokhtar, R. Jani, A. M. Zubairi, N. Othman, \& A. Gan. (Eds.), Enhancing the Quality of Higher Education through Research: Shaping Future Policy (pp. 160-179). The Ministry of Higher Education, Malaysia (MoHE), Kuala Lumpur.

Odlin, T. (1989). Language Transfer. Cambridge: Cambridge University Press.http://dx.doi.org/10.1017/CBO9781139524537

Olson, D. R., \& Torrance, N. (Eds.). (2009). The Cambridge Handbook of Literacy. Cambridge: Cambridge University Press. http://dx.doi.org/10.1017/CBO9780511609664

Pallant, J. (2010). SPSS Survival Manual: A Step by step guide to data analysis using SPSS. Buckingham Open University Press.

Phakiti, A and Li, L. (2011). General Academic Difficulties and Reading and Writing Diffficulties among Asian ESL Postgraduate Students in TESOL at an Australian University. RELC Journal, 42(3), 227-264. http://dx.doi.org/10.1177/0033688211421417

Pretorius, E. J. (2005). What do students do when they learn to read? Lessons from five case studies. South African Journal of Higher Education, 19(4), 790-812.

Rabab’ah, G. ( 2003). Communicating problems facing Arab learners of English. Journal of Language and Learning, 3(1), 180-197.

Reid, I., Kirkpatrick, A., \& Mulligan, D. (1998). Framing Reading. Perth : National Centre for English Language Teaching and Research with the Centre for Literacy, Culture, and Language Pedagogy at Curtin University of Technology.

Reinties, B., Beausaert, S., Grohnert, T., Niemantsverdriet, S., \& Kommers, P. (2012). Understanding academic performance of international students: the role of ethnicity, academic and social integration. Higher Education. 63, 685-700. doi: 10.1007/s10734-011- 9468-1.

Ringbom, H. (1987). The Role of the First Language in Foreign Language Learning. Clevedon, Philadelphia: Multilingual Matters Ltd.

Rubin, A., \& Babbie, E. R. (2009). Essential Research Methods for Social Work. Belmont, CA:Cengage Learning.

Sawir, E. (2005). Language difficulties of international students in Australia: The effects of prior learning experience. International Education Journal, 6, 567-580.

Schein, E. H. (2004). Organizational Culture and Leadership. San Francisco: Jossey-Bass.

Shi, L., \& Becket, G. (2002). Japanese exchange students' writing experiences in a Canadian University. TESL Canada Journal, 20, 38-56.

Smith, D. (1998). In O.Zuber-Skeritt and Y. Ryan (eds.), Enhancing a postgraduate learning and teaching of international students. Paper presented at HERDSA conference, Adelaide. 
Spack, R. (2004). The acquisition of academic literacy in second language: A longitudinal case study, updated. In V. Zamel \& R. Spack (Eds.), Crossing the curriculum: Multilingual learners in college classrooms (pp.19-45). Mahwah, NJ: Lawrence Erlbaum.

Stewart, D. W., \& Spille, H.A. (1988). Diploma Mills: Degrees of Fraud. New York NY: American Council on Education and Macmillan.

Street, B. V. (Ed.). (1993). The new literacy studies. In E. Cushman, E. R. Kintgen, B. M. Kroll, \& M. Rose (Eds.), Literacy: A critical sourcebook (pp. 430-442). Boston: Bedford/St. Martins. (Reprinted from Cross-Cultural Approaches to Literacy, pp. 1-21, by B. Street, Ed., 1993, London: Cambridge University Press.

Teddlie, C., \& Tashakkori, A. (2009). Foundations of mixed methods research. Thousand Oaks, CA: Sage.

Teddlie, C., \& Yu, F. (2007). Mixed methods sampling: A typology with examples. Journal of Mixed Methods Research, 1, 77-100. http://dx.doi.org/10.1177/2345678906292430

Trotter, E., \& Roberts, C. A. (2006). Enhancing the early student experience. Higher Education Research \& Development, 25(4), 371-386. http://dx.doi.org/10.1080/07294360600947368

Van Meter, P., Yokoi, L., \& Pressley, M. (1994). College students' theory of note-taking derived from their perceptions of note-taking. Journal of Educational Psychology, 86, 323-338. http://dx.doi.org/10.1037/0022-0663.86.3.323

Wahiza, W, O’Neille, M., \& Chapman, A. (2012). Exploring academic literacies of ESL Undergraduate Students. Paper presented at International Conference of Innovation Research in a Changing and Challenging World at Phuket, Thailand. Organized by Australian Multicultural Interaction Institute (AUMII). Retrieved from www.auamii.com/conference.html.

Wilson, K. (2003). 'Assisting ANESB students to acquire academic language skills'. In A, Bartlett, \& K, Chanock. (Eds.), The missing part of the student profile jigsaw: academic skills advising for Australian tertiary students from non-English speaking backgrounds. Canberra: Academic Skills and Learning Centre: ANU.

Wong, J. K. (2004). Are the learning styles of Asian internationals culturally or contextually based? International Education Journal, 4(4), 154-166.

Zamel, V., \& Spack, R. (Eds.), (2004). Crossing the curriculum: Multilingual learners in college classrooms. Mahwah, NJ: Lawrence Erlbaum.

Zhu, W. (2001). Performing argumentative writing in English: Difficulties, processes, and strategies. TESL Canada Journal, 19, 34-50.

\section{Copyrights}

Copyright for this article is retained by the author(s), with first publication rights granted to the journal.

This is an open-access article distributed under the terms and conditions of the Creative Commons Attribution license (http://creativecommons.org/licenses/by/3.0/). 